\title{
Studi ketertarikan ikan di keramba jaring apung terhadap warna cahaya lampu di perairan Sindulang I, Kecamatan Tuminting, Kota Manado
}

\author{
Study of the attraction of fish in a floating net cage on light colours in the Sindulang I waters, \\ District of Tuminting, Manado
}

\author{
FELIX URBASA*, FRANGKY E. KAPARANG dan HENRY J. KUMAJAS
}

Program Studi Pemanfaatan Sumberdaya Perikanan, Fakultas Perikanan dan Ilmu Kelautan, Universitas Sam Ratulangi, Manado 95115

\begin{abstract}
The use of light as a fishing aid is actually very related to the effort of fishermen to understand fish behavior and to respond to environmental changes. This research aims to study the fish attraction to the light of different colors, to study species of fish and shape of fish schools that are interested in a particular color of light. This research was conducted in Sindulang I waters, District of Tuminting, Manado. Observations in floating net cages was made directly and also by using a camera. To measure the intensity of light in water, the sensor of lux meter was inserted in a small tube size $5 \mathrm{~cm}$ high and then dipped $4 \mathrm{~cm}$ in the water. This study used four modified underwater LED lights. Fish were more interested in white and green colors than in blue and red. The most preferred color is white.
\end{abstract}

Keywords: light color, LED, floating net cage, Manado Bay

\begin{abstract}
ABSTRAK
Pemanfaatan cahaya sebagai alat bantu penangkapan ikan sesungguhnya sangat berkaitan dengan upaya nelayan dalam memahami perilaku ikan dan merespon perubahan lingkungan yang ada di sekitarnya. Penelitian ini bertujuan untuk mempelajari ketertarikan ikan terhadap warna cahaya lampu yang berbeda, mempelajari jenis ikan dan bentuk gerombolan ikan yang tertarik pada warna cahaya lampu tertentu. Penelitian ini dilakukan di Perairan Sindulang I, Kecamatan Tuminting Kota Manado. Pengamatan pada keramba jaring apung dilakukan secara langsung dan dengan menggunakan kamera. Untuk mengukur intensitas cahaya di dalam air maka, sensor lux meter dimasukkan dalam tabung kecil ukuran tinggi $5 \mathrm{~cm}$ lalu dicelupkan kedalam air sedalam $4 \mathrm{~cm}$. Pada penelitian ini digunakan empat lampu LED modifikasi bawah laut. Ikan lebih tertarik pada warna putih dan hijau dibandingkan dengan warna biru dan merah. Warna yang paling disukai adalah warna putih.
\end{abstract}

Kata-kata kunci: warna cahaya lampu, LED, karamba jaring apung, Teluk Manado

\section{PENDAHULUAN}

Indonesia merupakan salah satu negara kelautan yang sebagian besar wilayahnya terdiri dari perairan laut, di mana di dalamnya terkandung berbagai macam jenis sumberdaya hayati potensial yang dapat dimanfaatkan secara optimal sebagai sumber bahan pangan dan komoditi perdagangan. Hal ini sangat penting untuk perkembangan perikanan dan merupakan peluang bagi Indonesia untuk me-

\footnotetext{
*Penulis untuk penyuratan; email: felixurbasa@yahoo.com
}

ngembangkan perikanan menjadi salah satu primadona yang sangat ekonomis.

Pada awalnya penggunaan lampu sebagai alat bantu penangkapan ikan hanya terbatas pada perikanan tradisional yang terletak di pantai saja, seperti perikanan pukat pantai, sero, dan beberapa alat tangkap bagan lainnya. Namun, seiring dengan berkembangnya kegiatan perikanan tradisional menjadi industri, pemanfaatan cahaya sebagai alat bantu berkembang luas untuk membantu penangkapan ikan pada perikanan pukat cincin, bagan, stick held deep nets, dan lain-lain. 
Ketertarikan ikan dengan cahaya lampu dipengaruhi oleh beberapa faktor antara lain warna lampu, intensitas cahaya, lama penyinaran, kondisi perairan dan kondisi ikan. Untuk mencari tahu perbedaan warna lampu terhadap hasil tangkapan ikan, maka perlu dilakukan penelitian tentang perbandingan warna-warna lampu yang berbedabeda (lampu warna putih, biru, merah dan hijau). Penelitian bertujuan untuk: 1). mempelajari ketertarikan ikan terhadap warna cahaya lampu yang berbeda; 2). mempelajari jenis ikan dan bentuk gerombolan ikan yang tertarik pada warna cahaya lampu tertentu.

\section{METODE PENELITIAN}

Penelitian ini dilakukan di keramba jaring apung di perairan Sindulang I, Kecamatan Tuminting Kota Manado pada posisi geografis antara $1^{\circ} 30^{\prime}$ 31.30" N 12446'53.39". Pengumpulan data dilakukan pada minggu pertama di bulan Oktober 2014. Penelitian ini dilakukan dengan mengikuti metode deskriptif yang didasarkan pada studi kasus. Metode deskriptif adalah suatu metode yang tujuannya untuk memberikan gambaran secara sistematis, faktual dan akurat tentang fakta, sifat serta hubungan antara fenomena, menguji hipotesa, membuat prediksi dan mendapatkan makna serta implikasi dari masalah yang diselidiki, sedangkan studi kasus (case study) adalah mempelajari kasus tertentu pada objek yang terbatas (Nazir, 1985). Dalam hal ini penggunaan empat warna cahaya lampu dalam operasi penangkapan ikan.

Teknik pengumpulan data dilakukan mulai pada saat persiapan di atas keramba yakni mengukur panjang, lebar keramba jaring apung, tinggi jaring keramba, mendata jenis, ukuran dan jumlah ikan yang ada dalam keramba jaring apung. Kemudian di atas pintu keramba dipasang kwadran dari benang dengan jarak $10 \mathrm{~cm}$. Pada malam hari sebelum lampu diturunkan kamera dipasang terlebih dahulu pada posisi tengah-tengah keramba, kemudian lampu diturunkan secara berturut-turut mengikuti warna.

Tunggu kurang lebih 1 sampai 2 menit untuk mengamati gerakan ikan, setelah gerakan ikan sudah mulai teratur, maka rekaman kamera siap dihidupkan. Setelah lampu pertama warna hijau diturunkan 15 menit, demikian seterusnya lampu LED warna biru, merah dan putih dipasang pada keempat sudut pintu keramba. Untuk pengukuran intensitas cahaya di dalam air, maka sensor lux meter dimasukkan di dalam tabung kecil ukuran tinggi $5 \mathrm{~cm}$ lalu dicelupkan ke dalam air sedalam 4 $\mathrm{cm}$. Satu saja lampu warna LED yang dihidupkan, jarak sensor dengan lampu $10 \mathrm{~cm}, 20 \mathrm{~cm}$ dan seterusnya sampai $80 \mathrm{~cm}$. Pada penelitian ini digunakan empat buah lampu LED modifikasi bawah laut, di mana dilakukan penempatan lampu dengan jarak antara lampu yang satu dengan yang lainnya adalah $60 \mathrm{~cm}$ dan lampu dimasukkan ke dalam laut dari batas permukaan air adalah $1 \mathrm{~m}$. Pemasangan lampu LED bawah air ini dilakukan selama dua hari saat bulan 12 sebelum bulan purnama, dan pemasangan keempat buah lampu tersebut dipasang secara acak warna. Pengamatan pada keramba jaring apung dilakukan secara langsung dan dibantu juga dengan menggunakan kamera yang dipasang pada tengah keramba jaring apung. Penempatan lampu pada keempat sudut keramba jaring apung dipasang secara acak dan diberi pencahayaan kurang lebih 15 menit untuk hari pertama dan 60 menit untuk hari kedua (untuk dijadikan pembanding), kemudian dilakukan penukaran posisi lampu.

\section{HASIL DAN PEMBAHASAN}

\section{Keramba jaring apung}

Keramba jaring apung (KJA) yang digunakan adalah sejenis kurung-kurung bagan dengan ukuran keramba panjang $4 \mathrm{~m}$ dan lebar 2,5 m dengan tinggi badan jaring ke dalam laut $3 \mathrm{~m}$. Jenis ikan yang ada di dalam keramba jaring apung yang dilihat dalam pengamatan ada 3 jenis yaitu bubara, baronang dan ketan-ketan putih.

\section{Intensitas cahaya}

Pengukuran intensitas cahaya menggunakan Multifunction Environment Meter (light meter), waktu pengamatan dimulai pada jam 20.00-21.00 wita untuk pengukuran hari pertama. Saat pengukuran intensitas cahaya, lampu dimatikan secara bergantian untuk menghindari ikan yang sudah berkumpul dekat dengan cahaya nantinya akan menghilang atau menjauh. Menurut Sudirman dan Mallawa (2004), kemampuan ikan untuk tertarik pada suatu sumber cahaya sangat berbeda-beda; ada ikan yang tertarik dengan intensitas yang rendah, adapula yang tertarik oleh cahaya dengan intensitas tinggi. 
Tabel 1. Pengukuran intensitas cahaya

\begin{tabular}{cccccc}
\hline No & Jarak $(\mathrm{cm})$ & \multicolumn{4}{c}{ Intensitas cahaya (Lux) } \\
\cline { 3 - 5 } & & Hijau & biru & Merah & Putih \\
\cline { 3 - 5 } & 10 & 163 & 161 & 161 & 196 \\
2 & 20 & 140 & 140 & 140 & 177 \\
3 & 30 & 122 & 129 & 129 & 158 \\
4 & 40 & 102 & 112 & 112 & 124 \\
5 & 50 & 81 & 92 & 92 & 101 \\
6 & 60 & 61 & 71 & 71 & 78 \\
7 & 70 & 40 & 56 & 56 & 59 \\
8 & 80 & 26 & 33 & 33 & 35 \\
\hline
\end{tabular}

\section{Ketertarikan ikan terhadap warna cahaya}

\section{Warna tunggal}

Lampu dinyalakan pada pukul 20.00 wita kemudian melakukan pengamatan yang dilakukan untuk lampu warna putih pada hari pertama adalah 15 menit, dari hasil yang diamati pada 15 menit interval 5 menit awal. Pergerakan ikan mendekati lampu putih dalam waktu 15 menit, pada kwadran kedua terlihat 3 ekor, kwadran ketiga terlihat 5 ekor dan pada kwadran kelima terlihat 7 ekor. Waktu yang dilakukan untuk pengamatan hari pertama untuk lampu warna hijau adalah15 menit, hasil yang didapati adalah pergerakan ikan pada hari pertama terlihat bawah, pada kwadran ke dua terlihat 2 ekor, kwadran ketiga 1 ekor.

Pengamatan yang dilakukan pada lampu warna biru pada hari pertama adalah 15 menit dan hasil yang didapati adalah pergerakan ikan bobara untuk 5 menit awal, ikan yang tadinya menyebar dalam keramba mulai mendekat ke warna cahaya biru, yang dalam pengamatan ada 3 ekor kemudian pada interval 10 sampai 15 menit ada sekitar 5 sampai 7 ekor yang mendekat ke warna cahaya biru. Ikan bobara mendekat ke warna cahaya biru tetapi dua jenis ikan yang ada dalam keramba yakni ikan baronang dan ketan-ketan putih tidak terlihat mendekati warna cahaya biru. Pergerakan ikan mendekati lampu biru dalam waktu 15 menit terlihat pada Tabel 2, pada kwadran kedua terlihat 2 ekor, pada kwadran ketiga terlihat 3 ekor dan pada kwadran kelima terlihat 6 ekor.

Pengamatan yang dilakukan untuk lampu warna merah pada hari pertama adalah 15 menit dan hasil yang didapati untuk ikan bobara untuk 5 menit awal, tidak ada ikan yang mendekat terlihat blank/kosong kemudian pada 10 dan 15 menit berikutnya ikan yang mendekat dan kelihatan pada pengamatan 15 menit adalah 1 ekor. Ikan yang mendekat ke arah cahaya warna merah adalah ikan bobara dengan ukuran yang besar $25 \mathrm{~cm}$, sedangkan yang ukuran kecil semuanya menjauh dari warna cahaya merah.

Sehubungan dengan adanya perbedaan warna, ternyata sebagian besar ikan memiliki kemampuan untuk membedakan warna (Gunarso, 1985). Ikanikan yang hidup pada lapisan perairan yang relatif dangkal, banyak menerima cahaya matahari pada waktu siang hari, sehingga mampu membedakan warna cahaya sama halnya dengan manusia.

\section{Multi warna}

Pengamatan yang dilakukan dengan warna campuran dilakukan pada hari kedua, ikan terlihat masih tetap tertarik pada satu warna cahaya. Jarak antara lampu yang terpasang hanya $60 \mathrm{~cm}$.

Tabel 2. Jumlah ikan dalam kwadran per warna lampu dalam 15 menit.

\begin{tabular}{lccccc}
\hline Warna & Kw 1 & Kw 2 & Kw 3 & Kw 4 & Kw 5 \\
\hline Putih & 0 & 3 & 5 & 0 & 7 \\
Hijau & 0 & 2 & 1 & 0 & 0 \\
Biru & 0 & 2 & 3 & 0 & 6 \\
Merah & 0 & 1 & 0 & 0 & 0 \\
\hline
\end{tabular}




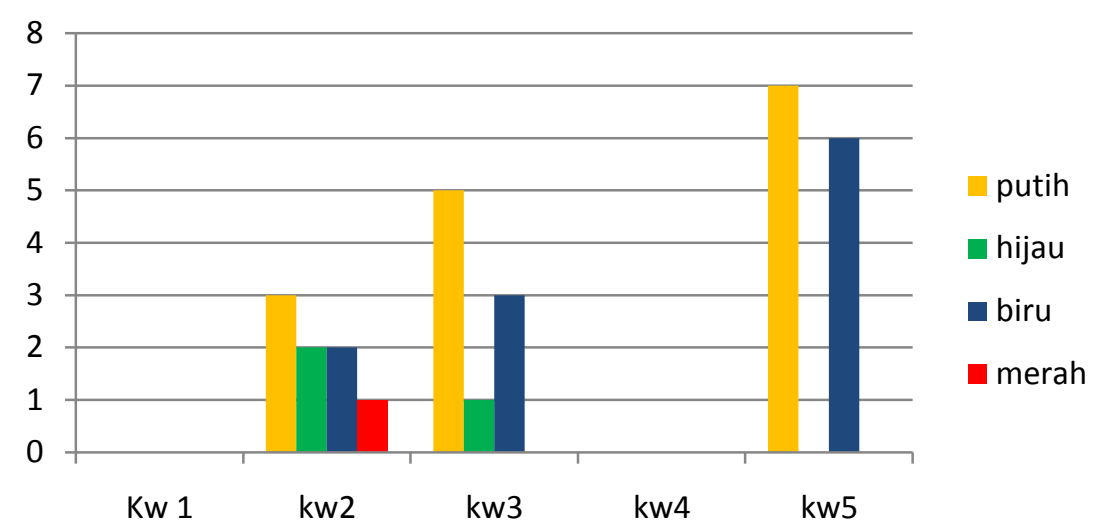

Gambar 1. Grafik pergerakanikandalam kwadran 4 (empat) warna lampu putih, hijau, biru dan merah selama 15 menit.

Tabel 3. Jumlah ikan dalam pengamatan 60 menit untuk empat warna cahaya pembandingan

\begin{tabular}{cccccc}
\hline Waktu & \multicolumn{5}{c}{ Warna } \\
\cline { 2 - 6 } (Menit) & Putih & Hijau & Biru & Merah & Ket. \\
\hline 5 & - & - & - & - & \\
10 & 12 & 5 & 2 & - & \\
15 & 15 & 7 & 4 & 1 & \\
20 & 17 & 11 & 7 & 1 \\
25 & 19 & 14 & 9 & 1 \\
30 & 23 & 17 & 11 & 1 \\
35 & 25 & 19 & 13 & 2 \\
40 & 28 & 21 & 17 & 3 \\
45 & 33 & 23 & 19 & 5 \\
50 & 36 & 26 & 21 & 7 \\
55 & 40 & 29 & 23 & 8 \\
60 & 44 & 32 & 26 & \\
\hline
\end{tabular}

Pada Gbr. 1 memperlihatkan bahwa untuk keempat warna cahaya lampu warna putih, hijau, biru dan merah yakni pada menit ke 5, ikan bubara dan baronang serta ikan ketan-ketan putih masih terlihat kosong atau ikan masih belum terlihat mendekat ke lampu atau masih merata ke semua permukaan di dalam keramba. Pada menit ke 10 untuk warna cahaya putih sudah terlihat 12 ekor, untuk warna cahaya hijau ikan yang mendekat ada 5 ekor dan untuk warna cahaya biru sama merah ikan belum terlihat sama sekali.

Pada menit ke 15 untuk warna cahaya putih ikan yang mendekat sudah mencapai 15 ekor dan pada warna cahaya hijau terlihat ada 7 ekor, warna cahaya biru ada 4 ekor serta warna cahaya merah ikan belum terlihat sama sekali mendekat, dan jenis ikan yang mendekat ke tiga warna cahaya putih, hijau dan biru pada menit ke 15 ini masih di dominasi oleh ikan bubara.
Pengamatan pada menit ke 20 pada warna cahaya putih ikan yang mendekat ada 17 ekor, pada warna cahaya hijau ikan ada 11 ekor, warna cahaya biru terlihat mendekat ada 7 ekor dan pada warna cahaya merah ikan yang mendekat baru terlihat 1 ekor. Pada menit ke 25 untuk pengamatan ini pada warna cahaya putih ikan semakin mendekat atau bertambah menjadi 19 ekor, untuk warna cahaya hijau ikan yang mendekat ada 14 ekor, warna cahaya biru 9 ekor dan untuk warna cahaya merah ikan yang mendekat dan berputar di sekitar warna cahaya merah masih terlihat 1 ekor.

Pada menit ke 30 untuk warna cahaya putih ikan yang mendekat dalam pengamatan ini ada 23 ekor, warna cahaya hijau terlihat ikan ada 17 ekor, untuk warna cahaya biru ikan yang mendekat dan berputar ada 11 ekor dan cahaya warna merah masih terlihat 1 ekor, pada menit ke 30 ini jenis 
ikan yang terlihat mendekat pada 2 (dua) warna cahaya yaitu warna cahaya putih dan hijau sudah bukan lagi ikan bubara, tetapi 2 jenis ikan lainnya yaitu ikan baronang dan ikan ketan-ketan putih juga sudah terlihat mendekat dan mulai berputar di sekitar warna cahaya putih dan hijau.

Pada menit ke 35 ikan yang mendekat ke warna cahaya putih 25 ekor, untuk warna cahaya hijau ikan ada 19 ekor, warna cahaya biru ada 13 ekor dan pada warna cahaya merah ikan masih terlihat 1 ekor namun ikan yang terlihat pada warna cahaya merah jenisnya ikan bubara dengan ukuran yang besar sekitar $25 \mathrm{~cm}$ dan ikan dengan ukuran sekitar $15 \mathrm{~cm}$ semuanya terlihat menjauh dari warna cahaya merah. Pada pengamatan menit ke 40 ikan yang mendekat dan berputar serta ada sebagian ikan bubara yang bergerak lurus dengan arah arus untuk warna cahaya putih ada 28 ekor, untuk warna cahaya hijau ikan yang mendekat ada 21 ekor dan jenis yang terlihat ikan bubara, ikan baronang dan ketan-ketan putih. Untuk warna cahaya biru ikan terlihat pada menit ke 40 ini ada 17 ekor dan untuk warna cahaya merah ikan bubara yang terlihat ada 2 ekor.

Pada menit ke 45 terlihat ikan mendekat dan berputar di warna cahaya putih ada 33 ekor, untuk warna cahaya hijau ikan yang mendekat ada 23 ekor, warna cahaya biru ikan ada 19 ekor dan warna cahaya merah ada 3 ekor. Pada warna cahaya biru dan merah dalam waktu 45 menit ini, ikan yang terlihat hanya jenis bubara sedangkan untuk ikan jenis baronang dan ketan-ketan putih tidak terlihat. Pada pengamatan di menit 50 ini untuk warna cahaya putih ikan mulai bergerombol dan ada sebagian berputar dengan arah arus ada 36 ekor, sedangkan untuk warna cahaya hijau ikan yang mendekat ada 26 ekor, warna cahaya biru ada 21 ekor dan pada warna cahaya merah terlihat 5 ekor.

Pada pengamatan di menit 55 pada warna cahaya putih ikan yang mendekat ada 40 ekor, untuk warna cahaya hijau ikan yang mendekat ada 29 ekor, warna cahaya biru ada 23 ekor dan warna cahaya merah sudah terlihat 7 ekor. Untuk menit ke 60 ikan bubara, baronang dan ikan ketan-ketan putih yang mendekat ke warna cahaya putih ada 44 ekor dan pada lampu warna hijau ada 32 ekor. Sedangkan pada warna cahaya biru ikan yang mendekat ada 26 ekor dan pada warna cahaya merah ada 8 ekor.Pada kedua warna cahaya biru dan merah untuk menit ke 60 ini terlihat hanya jenis ikan bubara sedangkan untuk jenis baronang dan ikan keta-ketan putih terlihat menjauh dari kedua warna cahaya tersebut.

Menurut Sudirman dan Mallawa (2004), kemampuan ikan untuk tertarik pada suatu sumber cahaya sangat berbeda-beda; ada ikan yang tertarik dengan intensitas yang rendah, adapula yang tertarik oleh cahaya dengan intensitas tinggi. Namun adapula ikan yang tertarik oleh cahaya mulai dari intensitas yang rendah sampai yang tinggi.

Dijelaskan oleh Laevastu dan Hayes (1991), ikan sudah memberikan reaksi dengan adanya rangsangan antara 0,01-0,001 lux. Selanjutnya Woodhead (1966) dalam Gunarso (1985) menyatakan bahwa sensitivitas mata ikan laut pada umumnya tinggi. Jika cahaya biru-hijau yang mampu diterima mata manusia hanya sebesar $30 \%$ saja, maka mata ikan mampu menerimanya sebesar $75 \%$, sedangkan retina mata dari beberapa jenis ikan laut dalam dapat menerimanya hingga $90 \%$.

\section{KESIMPULAN}

Ikan lebih tertarik pada warna putih dan hijau dibandingkan dengan warna biru dan merah. Warna yang paling disukai adalah warna putih. Ada jenis ikan objek yang sama menyukai dan mendekati warna cahaya putih dan hijau; dalam pengamatan adalah ikan bobara, baronang dan ikan ketan-ketan putih serta bentuk gerombolannya pada bagian bawah berputar mengelilingi cahaya dan pada bagian atas ikan bergerak lurus terhadap arus.

\section{DAFTAR PUSTAKA}

Gunarso, W. 1985. Tingkah laku ikan dalam hubungannya dengan alat, metoda dan taktik penangkapan. Fakultas Perikanan Institut Pertanian Bogor, Bogor.

Laevastu, T. and M.L. Hayes. 1991. Fisheries Oceanography and Ecology. Fishing News Books, Farnham.

Nazir, M. 1985. Metode Penelitian. Ghalia Indonesia, Jakarta.

Sudirman dan Mallawa. 2004. Teknik Penangkapan Ikan. Rineka Cipta, Jakarta. 